\title{
Positiv kriminologi bør gi nye krav til programvirksomhet
}

\author{
Dosent Gunnar Vold Hansen, Høgskolen i Østfold, \\ Avdeling for helse-og sosialfag \\ e-post: gunnar.v.hansen@hiof.no ${ }^{1}$
}

\begin{abstract}
This article considers whether one should think differently about how to develop and approve correctional programs. The question arises out of an evaluation of the RUS Program, which was designed for the Norwegian Correctional Service. The evaluation indicates that program participants place greater emphasis on the internal processes in the group than they do on the program's different components. Unfortunately, there are continuing services to ensure that these processes can be maintained after program implementation. The Norwegian Correctional Service emphasizes theories rooted in the collective term Positive Criminology (e.g., desistance and restorative justice). In connection with their increased focus on Positive Criminology, I conclude that the process of program development and approval should place greater emphasis on how participants can be followed up after program implementation. ${ }^{*}$
\end{abstract}

\section{Innledning}

Kriminalomsorgen i Norge, så vel som i en rekke andre vestlige land tilbyr domfelte ulike former for programmer med sikte på å redusere gjentakelse av kriminell aktivitet. En stor del av disse programmene tar sikte på å endre risikofaktorer (kriminogene faktorer) i de domfeltes atferd (for eksempel rusbruk eller vold). For å sikre at de programmene som tilbys har en tilfredsstillende kvalitet, har mange land etablert akkrediteringsordninger der et program blir vurdert før det blir godkjent for allment bruk i kriminalomsorgen. For å få et program akkreditert, så må det vises at programmet er forankret i vitenskapelige prinsipper. I praksis innebærer det at man i stor grad har vært opptatt av å dokumentere at de prinsippene et program bygger på, fører til at man reduserer kriminogene faktorer (Maguire et al, 2010). De siste årene har oppmerksomheten i kriminalomsorgen

\footnotetext{
* Title in English: New requirements for program operations as a result of Positive Criminology.
} 
dreid fra et ensidig fokus på hva som skaper kriminalitet (kriminogene faktorer) til også å bli opptatt av hva som bidrar til at en person fjerner seg fra kriminell aktivitet (positiv kriminologi/desistance) (se for eksempel Ronel \& Elisha, 2011; McNeill et al, 2012; Ronel \& Segev, 2014). I denne artikkelen argumenterer jeg derfor for at dette bør få konsekvenser for hvilke kriterier man legger vekt på ved akkreditering av programmer i kriminalomsorgen.

Min argumentasjon tar utgangspunkt i en evaluering et pilotprosjekt der kriminalomsorgen prøvde ut et program «Kortprogram Rus». Gjennom denne evalueringen skal jeg vise at programmet satte i gang individuelle og ulike prosesser som støttet deltakernes motivasjon for å mestre rusproblemer og å fjerne seg fra kriminelle aktiviteter. På bakgrunn av dette stiller jeg derfor spørsmålet om akkrediteringsordningen bør legge større vekt på at det dokumenteres hvordan man som ledd i programmet følger opp individuell prosesser som understøtter deltakernes egne ønsker om å fjerne seg fra kriminell aktivitet.

\section{Kunnskapsstatus}

\subsection{Brukergruppen}

Rusproblemer har en sterk kobling til kriminalomsorgen. Den mest åpenbare koblingen er de rusproblemene de innsatte har. Om lag $2 / 3$ av alle innsatte hadde før de ble satt inn et forbruk av rusmidler som kan karakteriseres som et rusproblem (Skardhamar, 2002; Friestad \& Skog Hansen, 2004). Koblingen mellom rus og kriminalitet innebærer at sjansene for kriminell aktivitet var 2,8 til 3,8 ganger så stor for personer med et rusproblem som for andre grupper (Bennett et al, 2008). Det er god grunn til å tro at redusert rusbruk kan bidra til reduksjon i kriminell atferd (Koehler et al, 2013). Det er derfor ikke overraskende at det er satt i verk en rekke tiltak de siste årene for å hjelpe de innsatte til å redusere sine rusproblemer. Tiltak rettet mot de innsattes rusbruk er høyt prioritert i St.meld 37 (20072008) «Straff som virker - mindre kriminalitet - tryggere samfunn».

\subsection{Rustiltak i kriminalomsorgen}

I Norge synes rusbehandling i kriminalomsorgen å ha vært knyttet til tre ulike strategier. Ulike former for programmer, muligheter for å erstatte soning i fengsel med opphold på en rusbehandlingsinstitusjon og etablering av rusbehandlingstiltak i fengsel. I dag er mesteparten av de programmene som tilbys i norske fengsler en norsk tilrettelegging av et kanadisk program «National Substance Abuse Programme» (NSAP). Dette har vært gjennomført en omfattende evaluering av dette programmet med både intervjuer av 26 deltakere og kvantitative tester av 77 deltakere. Denne evalueringen viser stor grad av positive tilbakemeldinger fra 
deltakerne (Granheim et al, 2010). Programmet er nokså omfattende og hvis det skal gjennomføres fullt ut vil det ta 4-5 måneder å gjennomføre det. I tillegg er det slik at etter straffegjennomføringsloven $\S 12$ kan innsatte som har behov for det, få sone hele eller deler av straffen i behandlingsinstitusjon. De siste årene er det dessuten etablert rusmestringsenheter i en rekke fengsler. Dette er behandlingsenheter som befinner seg inne i fengslene og som i hovedsak er bemannet av personell fra spesialisthelsetjenesten (Heisholt 2013, Helgesen 2013).

En del av de metodene som benyttes i rusinstitusjoner benyttes også innen kriminalomsorgen for å hjelpe innsatte til å begrense sitt rusbruk. I denne sammenhengen er det særlig kognitiv atferdsterapi og motiverende samtaler som er dokumentert virkningsfulle (se for eksempel Bahr et al, 2012; McMurran, 2009; Lipsey \& Cullen, 2007). En stor del av de tiltakene som tilbys i norske fengsler er derfor kognitive programmer. Disse bygger blant annet på teknikker som motiverende samtaler, utvikling av sosiale ferdigheter og bruk av positive belønningssystemer. En del av den generelle forskningen som er gjort utenfor kriminalomsorgen tyder på at slike teknikker er effektive i forhold til å begrense deltakernes rusproblemer (Ogden et al., 2011). Det ser likevel ut som om rusbehandling har positive virkninger uansett hvilke faglige prinsipper man legger til grunn (Nordfjærn \& Varmdal, 2011).

Det er også klare indikasjoner i forskningen på rusbehandling i fengsler at det ikke er spørsmål om hvilken metode man benytter, det viktigste er at man gjør noe. Allerede Marsch (1998) konkluderte derfor med at det å gjøre noe, er bedre enn å gjøre ingenting. Et interessant spørsmål blir derfor om man er for fokusert på hvilke innholdskomponenter slike programmer har og heller burde fokusere mer på de prosessene som foregår i deltakergruppen. Kanskje man i større grad bør være opptatt av den individuelle prosessen som fører til at den enkelte deltaker kan mestre sitt rusproblem og fjerne seg fra kriminell aktivitet? I praksis betyr dette at jeg ønsker å fokusere på hva som skaper og opprettholder endring i deltakernes forhold til rus og kriminalitet.

\subsection{Positiv kriminologi}

Etter hvert har man utviklet en del teorier som i stedet for å legge vekt på hva som fører til kriminalitet, legger vekt på hva som bidrar til at folk blir lovlydige. Disse teoriene samles gjerne under en felles overskrift: Positiv kriminologi. Positiv kriminologi fokuserer først og fremst på hva som bidrar til at en person fjerner seg fra kriminell atferd for alltid, eller i alle fall for en tid (Ronell \& Elisha, 2011). Positiv kriminologi beskrives av Ronel \& Elisha (2011) som et perspektiv som forener en rekke teorier, modeller og tilnærminger. Dette perspektivet fyller, 
etter deres mening, et tomrom og kan bidra til utvidelse og utvikling av dette nye feltet innen kriminologi. Positiv kriminologi er ikke ment å tilbakevise eller erstatte de klassiske kriminologiske tilnærminger, men heller å representere et annet aspekt i den hensikt for å oppnå komplementaritet. Under den felles overskriften positiv kriminologi skjuler det seg en rekke ulike tilnærminger. Jeg skal her trekke frem teorier knyttet til begrepene roller, desistance og restorative justice. Grensene mellom de ulike begrepene er ikke tydelige og det er derfor en viss grad av overlapp mellom dem. Jeg skal likevel gi en kortfattet og skjematisk presentasjon av de elementene som jeg anser som relevante i denne sammenhengen.

Et perspektiv handler om roller. Mennesker foretar individuelle og selvstendige valg, og ofte bygger disse valgene på hva man anser seg tjent med å gjøre (Brox, 1995). Hva man anser seg tjent med å gjøre, påvirkes for en stor del av institusjonelle normer og kulturen for øvrig (Barth, 1969). I et fengsel utsettes de innsatte for et sterkt press inn i en rolle der kriminelle aktiviteter fremstilles som positive og forherliges (Wolff \& Draine, 2004; Christie, 2007). Dersom man kan få innsatte til å identifisere seg med andre roller, for eksempel som en familiefar, så kan det bidra til at de blir mer oppsatt på å fjerne seg fra rollen som kriminell (Magaletta \& Herbst, 2001; Lösel et al, 2012, Hansen et al, 2013). Aktiviteter som bidrar til at den innsatte ser seg selv i en ny rolle kan dermed medføre at kriminell aktivitet blir redusert (Ronel \& Segev, 2013).

Desistance kan oppfattes som egne ønsker om å slutte med kriminell atferd. McNeill et al (2012) peker på at hva som skaper desistance er avhengig av det enkelte individ og hvor vedkommende er i sitt liv. Enkelt sagt så er det opplevelsen av at det er for stor avstand mellom det vedkommende oppfatter som viktig i livet og det livet vedkommende virkelig fører, så skaper dette motivasjon for å gjøre noe også med sin kriminelle atferd.

Det tredje perspektivet jeg skal trekke frem her er restorative justice. Dette handler om å «gjøre rett igjen» - det vil si å få den kriminelle til å akseptere at den kriminelle handlingen var uakseptabel og gjerne å iverksette tiltak med sikte på å få gjerningspersonen til å angre sin handling overfor offer eller andre skadelidende (Van Ness, 2004).

Ved å knytte ulike perspektiver inn under en overskrift som positiv kriminologi, gir det muligheter til å se den kriminelle som et helhetlig menneske. Se at vedkommende er noe mer enn en kriminell, en rusmisbruker og så videre. I stedet kan man se kriminelle som individer med ulike problemer, ulike ønsker og ikke minst ulike «veier» vekk fra kriminalitet (Ronel \& Segev, 2014). Fokus i positiv kriminologi vil i stor grad være hvilke ressurser som finnes hos den enkelte og i vedkommendes nettverk. Det innebærer at det er behov for individuelle løsninger 
der man søker å nyttiggjøre seg de ressursene som finnes (Weaver \& McNeill, 2011). Mitt spørsmål er om programvirksomhet i tilstrekkelig grad tar hensyn til den forskningen som viser at fokus på positiv kriminologi faktisk bidrar til redusert residiv. Problemstillingen i denne artikkelen blir derfor: Innebaerer positiv kriminologi at man bør tenke annerledes om programvirksomhet?

\subsection{Kortprogram RUS}

Om lag $3 / 4$ av alle innsatte i norske fengsler soner en kortere dom enn 3 måneder (SSB, 2013). Det innebærer at de fleste innsatte har så korte dommer at de ikke kan nyttiggjøre seg de tilbudene om rusmestring som har vært tilbudt så langt. I Danmark har denne målgruppen en behandlingsgaranti. Det har medført at man i København har satt i gang «Projekt over muren» et samarbeidsprosjekt der København kommune og København fengsler yter et behandlingstilbud til de innsatte i fengslene (Projektplan 2007). I Norge er det ikke en slik behandlingsgaranti, men «Projekt over muren» har inspirert kriminalomsorgen til å utvikle programmet «Kortprogram RUS». Kortprogram RUS er et program som er utviklet for å være et tilbud til innsatte med korte dommer eller som er varetektsfengslet. Det er derfor vesentlig kortere enn andre tiltak som tilbys i kriminalomsorgen. Programmet har som målsetting å bevisstgjøre de innsatte på utfordringene med rus og gi den motivasjon og muligheter for å redusere sitt rusproblem. Innholdet $\mathrm{i}$ programmet bygger blant annet på evidensbaserte metoder, motiverende samtaler og relasjonsskapende arbeid. Metoden er kognitiv terapi, med den kognitive diamant og motivasjons- og endringssirkelen fra Prochaska \& DiClementes forandringsteori som det primære arbeidsredskap. Programmet tilbys med fire samlinger i løpet av fire uker. I tillegg er det ambisjoner om å engasjere andre deler av relevant helse- og sosialtjeneste både innenfor og utenfor kriminalomsorgen, med sikte på å bygge opp et samordnet og helhetlig tjenestetilbud som både kan følge opp den innsatte resten av soningstiden og etterpå. Programmet kan derfor ses på som et ledd i en helhetlig strategi med sikte på å legge forholdene til rette for at deltakerne kan få kontroll på sine rusproblemer og begrense eller slutte med sin kriminelle aktivitet. I denne artikkelen fokuserer jeg likevel bare på hvordan deltakerne har opplevd selve programmet. Artikkelen bygger på en evaluering av de første fire pilotene av programmet (Hansen, 2014)

\section{Datasamling og metode.}

Ut fra et ønske om å få et bredt perspektiv på hvordan programmet hadde fungert for deltakerne, valgte jeg et intensivt design med bruk av intervjuer (Danermark et al, 2003). Jeg valgte først å gjennomføre gruppeintervju med de syv deltakerne 
som hadde gjennomført den første piloten. Jeg antok at siden deltakerne hadde sittet sammen gjennom fire programsamlinger og diskutert nokså sensitive spørsmål seg i mellom så ville de kunne ha en åpen diskusjon også med meg. Det fungerte dårlig. Selv om det kom frem en del interessante synspunkter så var det vanskelig å få deltakerne til å snakke om hvordan de hadde opplevd innholdet $\mathrm{i}$ programmet og selve programgjennomføringen. Konsekvensen av dette var at resten av intervjuene med deltakerne ble gjennomført som individuelle intervjuer. I alt ble det gjennomført ni individuelle intervjuer med deltakere fra tre ulike programgjennomføringer, i tillegg til gruppeintervjuet fra den første programgjennomføringen. Intervjuene ble for to av programgjennomføringene gjennomført om lag to uker etter at programmet var avsluttet og innbefattet alle deltakerne som var villige til å stille opp og fortsatt var i fengselet. I tillegg ble det gjennomført intervju med en deltaker som hadde gjennomført programmet et halvt år tidligere og fortsatt sonet da deltakerne fra et senere program ble intervjuet. Utvelgelsen av informanter var det av praktiske hensyn kriminalomsorgen som sto for. I alt er det derfor samlet inn data fra 16 deltakere. Deltakerne var alle menn i alderen 20 til 50 år, og hadde fra 2 til 21 dommer. Også ansatte er intervjuet. I alt syv ansatte er intervjuet i tre gruppeintervjuer, fire ansatte var med på to gruppeintervjuer. De individuelle intervjuene med deltakerne varte normalt ca $20 \mathrm{mi}-$ nutter, noen litt lengre noen litt kortere. Intervjuene var semistrukturerte der jeg først oppfordret deltakerne til å si noe om hvilke tanker de satt igjen med etter at de hadde deltatt i programmet. Etter hvert ble samtalen mer styrt inn på de to hovedtemaene: Hva ved programmet hadde vært positivt og hva hadde vært negativt, og hvordan ble deres behov for oppfølging ivaretatt etter endt soning? Spørsmålet om ivaretakelse av oppfølging blir ikke belyst i denne artikkelen. De tre gruppeintervjuene med de ansatte varte mellom 1 og $1 \frac{1}{2}$ time hver.

Intervjuene ble tatt opp med digital opptaker og lydfilene ble overført til en pc der de ble lyttet gjennom flere ganger ved hjelp av dataprogrammet Olympus DSS Player. Ved første gangs gjennomlytting, så ble helhetsinntrykk notert. Lydfilene ble så på nytt lyttet gjennom for å finne frem til hvilke temaer deltakerne trakk frem. Også meningsfortetning og kategorisering ble i første omgang gjort direkte fra lydfilene (Kvale, 1997; Hansen, 2007). Utsagnene ble kategorisert i tre deler: om selve programmet, om oppfølging og en stor del også om deltakerens bakgrunn. Sentrale deler av intervjuene ble skrevet ut, men av hensyn til deltakernes anonymitet ble alle opplysninger om bakgrunn (kriminell løpebane, rusbruk, sosiale nettverk etc) som mange av deltakerne uoppfordret gjorde rede for, ikke skrevet ut. Tekstene ble så kategorisert på nytt og alle utsagnene som handlet om selve programmet ble fordelt på tre ulike temaer: Motivasjon, innhold og 
gruppeprosessen. I utgangspunktet ventet jeg å få tilbakemelding på hvilke av de innholdskomponentene og modellene som programlederne presenterte, deltakerne hadde opplevd som viktige og mindre viktige. Ved første gangs analyse av intervjuene kom det frem at deltakerne ikke var så veldig opptatt av de innholdskomponentene og modellene som ble presentert. Det var i stedet den muligheten programmet skapte for å støtte dem i en prosess mot en annen livsførsel som framsto som mest sentral. Dette er sentrale elementer i positiv kriminologi og gjennom en prosess med meningsfortetning (Miles \& Hubermann, 1994) fant jeg frem til de opplevelsene som deltakerne la mest vekt på. Tilslutt har jeg funnet frem til utsagn som viser hvordan teorier og erfaringer forankret i positiv kriminologi kan bidra til forståelse av de dataene som kom frem i undersøkelsen (Lemire \& al, 2012). Utsagnene som presenteres er delvis redigerte, blant annet for å unngå at deltakerne skal kunne identifiseres.

\subsection{Datapresentasjon}

Et sentralt spørsmål i alle intervjuene var hvilke deler av programmet deltakerne opplevde som viktige. Tilbakemeldingene på det spørsmålet var stort sett uklare. Det var tydelig at deltakerne ikke hadde opplevd at noen av elementene var viktigere enn andre. I stedet fremhevet mange av deltakerne som vi også skal se siden, prosessene som foregikk. Følgende uttalelse representerer hva mange synes å ha opplevd:

Det var ikke de ulike modellene som var viktige - det var det som kom ut av diskusjonene når vi snakket om de ulike modellene som var viktig. (Deltaker nr. 7)

Denne uttalelsen viser at innholdet også var av betydning, men at det viktige for deltakerne var at dette innholdet kunne brukes i en prosess.

Den utviklingen som deltakerne gikk gjennom i løpet av programmet begynte ved at de selv meldte seg på programmet. Begrunnelsene for at de gjorde dette var forskjellige. Her er noen eksempler:

Jeg har et stort rusproblem og er med på alt jeg kan av tilbud for å få orden på rusproblemet mitt. (Deltaker nr. 1)

Ikke alle, men en stor del av deltakerne var klare på at deltakelsen i programmet var motivert av et ønske om å få kontroll på rusmisbruket. Flere understreket også at dette ikke bare handlet om rusmisbruk, men også om å fjerne seg fra kriminaliteten: 
Jeg er veldig forberedt på å være rusfri når jeg kommer ut. Jeg har alt for mange dommer og jeg er ikke noe flink kriminell så jeg må slutte. (Deltaker nr. 1)

Flere av deltakerne var også opptatt av at deres atferd rammet deres nærmeste og at de ønsket å delta i programmet slik at de kunne ta større ansvar overfor sine nærmeste:

Hvorfor jeg begynte på kurset? Grunnen er at jeg blir litt voldelig sammen med rus - amfetamin - dette vil jeg ha slutt på. Når jeg kommer ut igjen vil jeg stille sterkest mulig til å bli såkalt ordentlig - jeg vil jobbe og være sammen med de jeg er glad i - ikke sant. Ikke drive med rus ikke drive med kriminalitet. (Deltaker nr. 2)

Felles for disse utsagnene er at deltakerne hadde innsett at de hadde et problem et problem som de ikke selv kunne løse alene og som de derfor trenger hjelp for. Det sentrale utgangspunktet for dem var derfor at de ønsket en endring - en endring som innebærer at de kunne fjerne seg både fra rus og fra kriminalitet.

Det siste utsagnet er også interessant for det understreker at denne endringen langt på vei var begrunnet om et ønske om å knytte seg tettere til familien. Dette understrekes også i følgende utsagn:

Jeg er opptatt av at jeg skal skikke meg av hensyn til familien - familien betyr mye for meg. (Deltaker nr. 6)

Det var også tydelig at programmet bidro til en utvikling av deltakernes forståelse av hvordan deres rusbruk rammet andre og at dette bidro til at deltakerne fikk et annet perspektiv på sitt eget rusbruk. Følgende uttalelse er et eksempel på denne erkjennelsen:

Jeg har begynt å tenke på annet enn meg sjøl - jeg har tenkt på hva jeg har ødelagt for andre. (Deltaker nr. 3)

Både denne og noen av de andre uttalelsene presentert foran, viser at deltakerne var opptatt av hvordan deres rusatferd og kriminalitet hadde rammet andre. De så derfor deltakelsen i programmet og bedre kontroll over rus og kriminalitet som et forsøk på å gjenopprette en del av disse skadene.

For de fleste deltakerne var det tydelig at det mest sentrale ved programmet hadde vært gruppeprosessen. Det innebar at flere av deltakerne ikke bare var opptatt av de forpliktelsene man hadde overfor familien og andre nærstående perso- 
ner, men også at fellesskapet i gruppen skapte forpliktelser. En av deltakerne uttalte dette på følgende måte:

Jeg har tro på sånne grupper - så fort du kommer inn i en gruppe så blir du sårbar overfor noen du begynner å like de folkene og du føler at du må følge opp - etter hvert blir det vanskelig å ruse seg - da skuffer du de andre - det vi alle har jobbet mot. (Deltaker nr. 1)

Denne uttalelsen peker også på hvordan gruppene bidro til at deltakerne fikk et annet bilde av hverandre. Dette er enda tydeligere i følgende utsagn:

Det å sitte i en gruppe og prate det var faktisk ikke så skummelt som jeg trodde.

Det var rart å sitte der med alle de tøffeste gutta og så begynte vi å prate ....og så ... ble vi sårbare alle sammen ... det gjorde at jeg fikk et helt annet inntrykk av folk som sitter fengslet enn det jeg har hatt gjennom de mange dommene jeg har hatt tidligere. (Deltaker nr. 5)

Dette nye bildet av de andre deltakerne, gjorde også at de innspillene de andre kom med ble viktige for dem. Her er to utsagn som viser hvordan mange av deltakerne opplevde de diskusjonene som foregikk i gruppen:

Hva var det viktigste ved programmet? - se andres rusproblemer - likheter - selv om vi er forskjellige, så er rusproblematikken prikk lik i mange tilfeller. Det å se hvor mange mennesker som går rundt i samme runddansen og sliter med samme problemene - det er ikke bare jeg som sliter. (Deltaker nr. 1)

Det var viktig å høre hvordan andre hadde det og hvordan de taklet forskjellige situasjoner. (Deltaker nr. 7)

Også andre deltakere understreket at erfaringene som de andre bidro med var viktige for dem. Dette handlet delvis om at de fikk forståelse for at andre egentlig opplevde de samme utfordringene og delvis om at de erfaringene andre formidlet og diskusjonene omkring disse, ga deltakerne innspill til å mestre sine egne utfordringer. Deltakergruppen ble et nettverk der deltakerne fungerte som ressurser for hverandre. Slik disse erfaringene ble beskrevet, fremstod dette som gjensidige prosesser der deltakerne både ga og fikk hjelp.

Selv om programmet var tilpasset deltakerne med korte dommer og enkelte deltakere til og med var blitt løslatt før programmet var avsluttet, var det fortsatt en del deltakere som hadde en del tid igjen før løslatelse. Disse var for en stor del samstemte om at programmet skulle ha vart lenger. Dette er en representativ uttalelse:

Jeg synes vi bare fikk så vidt begynt - vi fikk bare skrapa litt i overflaten. (Deltaker nr. 8) 
I norsk kriminalpolitikk har kontaktbetjentene en sentral rolle i å følge opp de innsatte. De prosessene og diskusjonene som programmet hadde satt i gang kunne derfor blitt fulgt opp med samtaler mellom kontaktbetjenter og deltakerne. Ingen av deltakerne beskrev en slik oppfølging. I stedet pekte noen på at det var vanskelig å få til. Delvis handlet dette om deltakerne selv og trolig om manglende tillit til kontaktbetjentene:

Jeg snakker ikke om problemene mine med kontaktbetjenten. (Deltaker nr. 8)

Delvis handlet dette om hvilke muligheter de hadde for å ta opp slike saker med kontaktbetjenten:

Jeg kan jo snakke med kontaktbetjenten, men det er vanligvis ikke tid - alle har så mye å gjøre og de har liksom ikke tid til hver og en. (Deltaker nr. 4)

Det kunne også tenkes at de samtalene og den utveksling av erfaringer som deltakerne fikk så mye ut av i gruppene kunne videreføres på mer uformell basis utenfor rammene av selve programmet. Tilbakemeldingene var likevel klare på at det skjedde i liten grad:

Om vi snakker om rusproblemene også utenom programsamlingene? Nei, jeg ser ikke så mye til de andre i det daglige. (Deltaker nr. 1)

Et problem er altså at forholdene ikke er lagt til rette slik at deltakerne i programmet kan omgås utenom programsamlingene. Et annet problem synes å være at man heller ikke der det er muligheter for å snakke om programmets temaer, gjør det. En av deltakerne forklarer:

Noen snakker jeg med etter møtene - men ikke mye, men det hender vi spør hverandre - hva skal du gjøre når du kommer ut - hva skal du endre på? Men vi snakker ikke så mye om det det er flere som snakker om hva de skal gjøre av dumme ting enn om bra ting. (Deltaker nr. 6)

I praksis synes det som om deltakerne for en stor del ble overlatt til seg selv etter at programmet er gjennomført. De opprettholdt ikke den positive kontakten de hadde etablert i selve deltakergruppen og de etablerte heller ikke en oppfølging gjennom å benytte kontaktbetjentene som samtalepartner. Det ser ut som om det var liten aksept for å snakke om rus på samme måte utenfor programgruppene som innenfor. Årsakene til at man ikke benyttet kontaktbetjentene, synes delvis å være at deltakerne selv ikke så kontaktbetjentene som relevante samtaleparter og 
delvis at ressurssituasjonen i fengslene var slik at de ikke fikk anledning til å snakke om slike saker.

\subsection{Drøfting}

Deltakerne hadde ikke noen samstemte tilbakemeldinger på hvilke deler av programmet som hadde vært viktigst. I stedet var det tydelig at programmet hadde satt i gang individuelle og delvis ulike prosesser hos deltakerne. Utgangspunktet for deltakerne var at hadde kommet der i livet at de innså at de hadde et rusproblem og at dersom de skulle få et liv de ønsket seg, så måtte de gjøre noe med det. For mange handlet dette om en noenlunde naturlig utvikling - det er grunn til å tro at både rusbruk og kriminell atferd blir mindre attraktivt etter hvert som årene går (McNeill et al, 2011). Motivasjon som er forankret i et grunnleggende ønske om en helt ny livsførsel beskrives av Kohler \& al (2013) som en sentral suksessfaktor for å få til endret atferd.

Det er likevel interessant å se at deltakerne for en stor del hadde ulike begrunnelser for sin motivasjon. Mange pekte på at de så programmet som et ledd i en prosess, et skritt i en ferd mot en ønskverdig fremtid. Noen ønsket å delta av hensyn til familien og andre nærstående personer, noen hadde fått nok av rus og noen var bare nysgjerrige på hva rusbehandling innebærer. Dette understreker det McNeill et al (2012) hevder, om at det som skaper desistance er avhengig av det enkelte individ og hvor vedkommende er i sitt liv. Samtidig ser vi også at en del av begrunnelsene hadde et element av «gjenoppretting» i seg. Delvis handlet det om å ta ansvar for at man har ødelagt for andre og delvis handlet det om å ta ansvar for familien. Restorative justice tar utgangspunkt $i$ at forståelsen for at man skader andre med kriminell aktivitet er en sentral faktor i prosessen mot et kriminalitetsfritt liv (Rowe, 2002). Noen av deltakerne understreket at det ikke bare var snakk om å unngå å skade familien, men at det også var viktig for dem å bli rusfrie slik at de kunne få delta aktivt i familielivet. Dersom de domfelte kan opprettholde og styrke kontakten med familien, så kan det bidra til en positiv utvikling på flere måter. For det første kan kontakt med familien ha en virkning på den domfelte mens vedkommende soner, dernest registreres det også virkning etter at soningen er avsluttet. Fokus på styrking av familiebåndene er sannsynligvis den sterkeste katalysatoren for å oppnå suksess i tilbakeføring fra fengsel til samfunnet. Dersom man styrker deltakernes fokus på ansvar for barn og familie og forstår de bedre at slikt ansvar ikke kan ivaretas skikkelig så lenge man ruser seg eller er i fengsel. (Loper \& Tuerk, 2007; Skardhamar \& Telle, 2009; Lösel et al, 2012) 
Deltakerne var veldig tydelige på at det som skjedde $\mathrm{i}$ gruppen var viktig for dem. At gruppeprosesser og andre innsattes erfaringer, er viktige er en tilbakemelding som gis i mange av rusbehandlingstilbudene som kriminalomsorgen tilbyr (se for eksempel Granheim et al, 2010; Nærum, 2013; Bergsgaard \& Danielsen, 2012; Heisholt, 2013). Det synes derfor å være en klar konklusjon at gruppeprosesser er et viktig element i slike tilbud. Trolig er det en rekke årsaker til at disse gruppene blir så viktige, men her skal jeg bare trekke frem en - rolleidentifikasjon.

Som alle andre lukkete institusjoner så kjennetegnes også fengsler av sin egen kultur. Denne er preget av normer som understøtter kriminelle aktiviteter (Wolff \& Draine, 2004; Christie, 2007). Den beskrivelsen som deltakerne ga av sine opplevelser i gruppene tyder på at de opplevde en annen kultur der. Normene for hva som var akseptabel atferd i gruppen synes vesentlig forskjellig for det som preger fengselssamfunnet ellers. Det synes som om det utviklet seg en egen alternativ kultur i disse gruppene - en kultur som i motsetning til fengselssamfunnet ellers aksepterer at man har en rolle der deltakerne kan vise svakheter og bli sårbare. Fengslene kjennetegnes ellers av at de innsatte skryter både av rusbruk og kriminalitet, og vi har tidligere sett eksempler på at innsatte som har ønsket å stille seg kritiske til rusbruk, har opplevd å bli mer eller mindre utfryst fra fellesskapet (Hansen \& Dahl, 2006).

For deltakerne i dette programmet ble gruppene en arena der de både kunne legge frem de utfordringene de opplevde og der de kunne få hjelp og støtte fra programledere og ikke minst fra de andre deltakerne. Det er særlig den hjelpen og støtten de fikk fra de andre deltakerne som fremheves. De pekte også på at gruppeprosessen gjorde at de følte forpliktelser overfor de andre deltakerne til å løse de utfordringene de stod foran. Det tyder på at gruppene ble en arena der det utvikles sosial kapital. Sosial kapital er ikke et entydig begrep, men Endresen \& Mo (2012) har prøvd å trekke ut de mest sentrale kjennetegnene fra klassiske forfattere (Bourdieu, Coleman og Putnam) og gir følgende beskrivelse av sosial kapital: «... gjensidig tillit og gjensidige forpliktelser innenfor nettverk som gjør det mulig for enkeltaktører og sosiale fellesskap å mobilisere ressurser og løse problemer». For deltakerne i dette programmet ser det ut som om gruppene nettopp blir et slikt nettverk, der den sosiale kapitalen handler om at deltakernes innspill i diskusjonene blir en ressurs for de andre. Dessverre ser det ut som om dette nettverket bare fungerte i programsamlingene. Den sosiale kapitalen som gruppene representerte forsvant derfor etter endt programgjennomføring.

Det danske «Projekt over Muren» som har vært inspirasjonen for Kortprogram RUS bygger på prinsippet om at de innsatte skal ha et tilbud gjennom hele 
soningen. Det virker som om Kortprogram RUS gjennom programperioden bidro til økt rusmestring for deltakerne, men dette synes å være et resultat av en aktiv prosess. Denne prosessen ble ikke videreført etter endt soning. Deltakerne kunne ikke fortsette sin samhandling med andre innsatte. Den muligheten for oppfølging som ligger i kontaktbetjentordningen ble heller ikke utnyttet. Deltakerne ble derfor i stor grad overlatt til seg selv og til et sosialt fellesskap i fengselet som ikke var opptatt av å løse utfordringer med rus og kriminalitet.

Kortprogram Rus var et tilbud som har passet deltakerne - det har bygget på deltakernes egne og ulike motivasjoner for å gjøre noe med livet sitt. Dernest har det bidratt til å understøtte deltakernes egen innsats mot rusmestring, blant annet ved at det er bygget opp sosial kapital der deltakergruppen har gitt hverandre både støtte og råd. Positiv kriminologi legger vekt på å tilby hjelp til å løse de utfordringene som den domfelte selv føler behov for å gjøre noe med og å hjelpe dem til å finne løsninger som de har tillit til og selv kan ta ansvar for å iverksette (Weaver \& McNeill, 2011; Ronel \& Segev, 2013). Programmet synes å ha satt i gang prosesser hos deltakerne som kan forstås under overskriften positiv kriminologi.

Også $\mathrm{i}$ andre programmer har vi sett at slike gruppeprosesser har vært en viktig del av deltakernes erfaringer og at deltakerne etterlyste en form for oppfølging etter at programmet var gjennomført (Hansen et al, 2012). Det er derfor god grunn til å tro at andre programmer i kriminalomsorgen også setter i gang viktige gruppeprosesser blant deltakerne og at disse prosessene ikke blir videreført fordi det ikke organiseres en oppfølging for deltakerne.

\section{Konklusjon}

Utfordringen med programvirksomheten slik den er organisert er at den er en tidsavgrenset aktivitet. Det ser ut som om kriminalomsorgen i stor grad tilnærmer seg de kriminogene faktorene som om dette er problemer som gjennom ulike tiltak kan løses helt. Realiteten er at rus og kriminalitet ofte er såkalte «wicked problems» (Rittel \& Webber, 1973). Dette er problemer der årsakene til problemene er uklare og der det sjelden er entydige og endelige løsninger. Dette er derfor problemer som sjelden kan løses helt, men der man kan sette i gang en prosess som kan redusere problemene. Kortprogram RUS har satt i gang en del prosesser hos deltakerne, men etter at programmet var avsluttet var det ikke lenger organisatoriske rammer som kunne understøtte disse prosessene. Det er derfor grunn til å frykte at den positive utvikling deltakerne rapporterte om, ikke opprettholdes for de av deltakerne som fortsatt har tid igjen av soningen fordi de ikke får en videre oppfølging i fengslet. 
I dette tilfellet handlet disse prosessene blant annet om at deltakerne fikk støtte til sine egne ønsker om å endre livsførsel, få en annen rolle i samfunnet og å gjenopprette en del av den skaden de har påført sine nærmeste. Slike prosesser er sentrale elementer i positiv kriminologi og synes å ha en klar forankring i norsk kriminalpolitikk (Hansen et al, 2014). Jeg har gjennom å beskrive erfaringene fra Kortprogram RUS vist at slike prosesser faktisk kan identifiseres i deltakernes beskrivelse av sine erfaringer.

Mitt utgangspunkt i denne artikkelen var spørsmålet: Innebcerer positiv kriminologi at man bør tenke annerledes om programvirksomhet? Slik denne programvirksomheten er organisert, mangler den organisatoriske rammer som kan sikre at de prosessene som settes i gang videreføres for de deltakerne som fortsatt har tid igjen av sin soning etter at programmet er avsluttet. Hvis man ønsker å forankre programvirksomheten også i positiv kriminologi, så må det etter min mening tenkes annerledes om hvilke krav man setter til de ulike programmene.

I Norge og en rekke andre land (blant annet Australia, Canada, Danmark, Sverige, England og Nederland) har man akkrediteringsordninger som skal sikre at de programmene som settes i gang er faglig forankret. Disse akkrediteringsordningene legger i dag stor vekt på at programmene skal dokumentere hvordan programmet ivaretar reduksjon i kriminogene faktorer (Maguire et al, 2010). Slik dokumentasjon knyttes gjerne til beskrivelser av hvordan adferdsterapeutiske metoder og modeller benyttes. Etter min mening bør det nå også være krav om at det ved akkreditering av programmer blir dokumentert hvordan man i løpet av programgjennomføringen skal kunne ivareta deltakernes individuelle prosesser forankret i positiv kriminologi og hvordan disse prosessene skal følges opp etter at programmet er gjennomført.

Mine data gir ikke noe klart svar på om vektlegging av positiv kriminologi bidrar til at målene med kriminalpolitikken nås. Dataene viser heller ikke om større vekt på oppfølging av deltakerne etter at det formelle programmet er avsluttet gir et annet resultat for deltakerne. Jeg mener likevel at det er grunnlag for å si at dersom man ønsker å legge vekt på elementene i positiv kriminologi, så må man ha større oppmerksomhet på hvordan deltakerne i et program blir fulgt opp etter endt programgjennomføring. Hvorvidt dette medfører at man får andre resultater av programvirksomheten enn nå, kan bare fremtidig forskning avsløre.

Artikkelen bygger på evalueringsrapporten «Kortprogram Rus»-Evaluering av et pilotprosjekt (Hansen, 2014) som var finansiert av Kriminalomsorgen region sør i Norge. 


\section{Note}

1. Gunnar Vold Hansen er dosent ved Høgskolen I Østfold, avdeling for helse- og sosialfag. Han er statsviter og har en doktorgrad i Arbeidsvitenskap. Han er for tiden knyttet til høgskolens masterstudium i tverrfaglig samarbeid i helse- og sosialsektoren. Hans forskning retter seg først og fremst mot organisering av helse- og sosialsektoren. Særlig har han vært opptatt av helhetlige tjenestetilbud for brukere med rus- og psykiske lidelser og/eller kriminell aktivitet.

\section{Litteraturliste}

Bahr, S.J., Masters, A.L., \& Taylor, B.M. (2012). What Works in Substance Abuse Treatment Programs for Offenders? The Prison Journal, 92(2), p. 155-174

Barth, F. (1969). Models of social organization. Royal anthropological institute of Great Britain and Ireland.

Bennett, T., Holloway, K., \& Farrington, D. (2008). The statistical association between drug misuse and crime: A meta-analysis. Aggression and Violent Behavior, 13(2), p. 107-118.

Bergsgard N.A., \& Danielsen T. (2012). Rehabilitering av rus-avhengige i fengsel - nytter det Rus \& Samfunn, 02/2013 p. 18-20

Brox, O (1995). Praktisk samfunnsvitenskap, 2. opplag, Universitetsforlaget, Oslo

Christie (2007). Sosial kontroll, i Finstad L \& Høigård C (red). Kriminologi, Pax Oslo

Danermark, B., Ekström M., Jacobsen, L. \& Karlsson, J.C. (2003). Att förklara samhället. Lund: Studentlitteratur.

Danermark, B., Ekström M., Jacobsen, L., \& Karlsson, J.C. (2003). Att förklara samhället, Lund: Studentlitteratur Lund

Endresen A. \& Moe S. (2012): «Arbeidsmiljøet blant NAV-ansatte sett i et sosial kapital perspektiv» Søkelys på arbeidslivet Årgang 29, no 01-02/2012 p. 3-20

Friestad, C., \& Skog Hansen, I.L. (2004). Levekår blant innsatte. Fafo-rapport 429, Oslo: Fafo

Granheim, P.K., Rustad, Å.B., \& Rokkan, T. (2010). Evalueringsrapport. National Substance Abuse Programe Oslo, Kriminalomsorgens utdanningssenter

Hansen, G.V. \& Dahl, U (2006). Alternative rusreaksjoner, HiØ Rapport 2006.3

Hansen, G.V. (2007): Samarbeid uten fellesskap - om individuelle planer i kommunalt psykisk helsearbeid, Karlstad University Studies 2007:15

Hansen, G.V. (2014). «Kortprogram Rus» - Evaluering av et pilotprosjekt, HiØ Oppdragsrapport 2014.3

Hansen, G.V., Dahl, U., \& Samuelsen, F. (2014). EVALUERING AV BRIK - Behovs- og ressurskartlegging $i$ kriminalomsorgen, HiØ Oppdragsrapport 2014.2

Hansen, G.V.; Arvesen, P; Tonholm, T (2013). Pappa i fengsel - andre evalueringsrapport; HiØ Oppdragsrapport 2013.18

Heisholt, H. (2013). «Når hovedprosjektet ditt er deg selv»: Muligheter og begrensninger for rusrehabilitering i fengsel. Masteroppgave, Universitetet i Oslo

Helgesen, J.H.I. (2013). Godt begynt er halvt fullendt?: Iverksetting av rusmestringsenheter $i$ norsk kriminalomsorg. Masteroppgave, Høgskolen i Lillehammer

Koehler, J.A., Humphreys, D.K., Akoensi, T.D., Sánchez de Ribera, O., \& Lösel F. (2013). A systematic review and meta-analysis on the effects of European drug treatment programs on reoffending, Psychology, Crime \& Law, 2013 
Kvale, S. (1997). Det kvalitative forskningsintervju. Oslo: Gyldendal Akademisk.

Lemire S.T., Nielsen S.B. and Dybdal L. (2012) Making contribution analysis work: A practical framework for handling influencing factors and alternative explanations, Evaluation 2012 18: 294

Lipsey, M.W., \& Cullen, F.T. (2007). The effectiveness of correctional rehabilitation: A review of systematic reviews. Annual Review of Law and Social Science 2007 3, p. 297-320.

Lipsey, M.W., Landenberger, N.A., \& Wilson, S.J. (2007). Effects of cognitive-behavioral programs for criminal offenders. Campbell Systematic Reviews 2007:6

Loper, A.B., \& Tuerk, E.H. (2006). Parenting programs for incarcerated parents. Current research and future directions. Criminal Justice Policy Review, 17.4: p 407-427

Lösel, F., Pugh, G., Markson, L., Souza, K.A., \& Lanskey, C. (2012): Risk and protective factors in the resettlement of imprisoned fathers with their families, Final Report, University of Cambridge.

Magaletta, P.R. \& Herbst, D.P. (2001). Fathering from prison: Common struggles and successful solutions. Psychotherapy: Theory, Research, Practice, Training, 38 (1), p. 88-96 American Physchological Association.

Maguire, M., Grubin, D., Lösel, F., \& Raynor, P. (2010). 'What Works' and the Correctional Services Accreditation Panel: Taking stock from an inside perspective. Criminology and Criminal justice, 10(1), p. 37-58.

Marsch, L.A. (1998). The efficacy of methadone maintenance interventions in reducing illicit opiate use, HIV risk behaviours and criminality: a meta-analysis. Addiction, 93(4), p. 515532.

McMurran, M. (2009). Motivational interviewing with offenders: A systematic review. Legal and Criminological Psychology, 14(1), p. 83-100.

McNeill, F., Farrall, S., Lightowler, C., \& Maruna, S. (2012). How and why people stop offending: discovering desistance. Institute for Research and Innovation in Social Services

Miles, M.B. \& Huberman, A.M. (1994). Qualitative Data Analysis, Thousand Oaks: Sage Publications

Nærum, E.J. (2013). Stifinner'n i Oslo fengsel: Et kryss på veien mellom fortid og framtid? Masteroppgave i rettssosiologi, Universitetet i Oslo

Nordfjærn, T., \& Varmdal, T. (2011). Perspektiver på SUKSESSKRITERIER. Rus \& Samfunn, 5(05), p. 32-34.

Ogden, T., Holth, P.E.R., \& Hassel Kristoffersen, C. (2011). HVA VIRKER: Unge og rusbehandling. Rus \& Samfunn, 5(05) p. 25-28

Projektplan (2007). Projekt Over Muren http:/www.kfkk.dk/professionel/projektets-basisdokumenter/projektplanen.aspx

Rittel, H.W., \& Webber, M.M. (1973). Dilemmas in a general theory of planning. Policy sciences, 4(2), 155-169.

Ronel, N., \& Elisha, E. (2011). A different perspective. Introducing positive criminology. International journal of offender therapy and comparative criminology, 55(2), p. 305-325.

Ronel, N., \& Segev, D. (2014). Positive criminology in practice. International journal of offender therapy and comparative criminology, 58(11), 1389-1407. Rowe, W. (2002). A metaanalysis of six Washington state restorative justice projects. Washington, Governor's Juvenile Justice Advisory Committee, Office of Juvenile Justice. 
Skardhamar, T. \& Telle K. (2009). Livet etter soning - hindrer arbeid tilbakefall? Samfunnsspeilet, 2009/4, p 47-53

Skardhamar, T. (2002). Levekår og livssituasjon blant innsatte i norske fengsler. Oslo: Universitetet i Oslo.

SSB (2013). Straffereaksjoner, 2011, http://www.ssb.no/straff,

Stortingsmelding nr. 37 (2007-08). «Straff som virker - mindre kriminalitet - tryggere samfunn»

Van Ness, D.W. (2004). Contemplating a restorative justice system. Paper presented at Building a Global Alliance for Restorative Practices and Family Empowerment, 5-7 August 2004. Richmond, B C, Canada.

Weaver, B., \& McNeill, F. (2011, September). Some Lessons from Research for Organising and Delivering Case Management Work with Offenders. In The Scottish Centre for Crime \& Justice Research. DOMICE, Final Conference, Barcelona.

Wolff, N. \& Draine, J. (2004). Dynamics of Social Capital of Prisoners and Community Reentry. Ties That Bind? Journal of Correctional Health Care (10)3, p. 457-90. 